\section{Narrativa jornalística: a história de Lula contada pelos jornais espanhóis ${ }^{1}$}

\section{RESUMO}

0 artigo relata um conto para chamar a atenção para a riqueza dos elementos literários contidos na trajetória de vida de Lula, atual presidente da República. A história tem força narrativa suficiente para, por si própria, impor-se como valor principal de uma narrativa jornalística onde se supõe que deveria reinar a linguagem da objetividade e da racionalidade. É este relato literário que predomina como valor-notícia na narrativa dos jornais espanhóis. Esta será a análise de quatro jornais da Espanha, no período que vai de $1^{\circ}$ de outubro a 3 de novembro de 2002, tempo em que os jornais dedicaram ampla cobertura às eleições brasileiras.

\section{ABSTRACT \\ This article analyses how Spanish newspapers reported in a literary style, instead of the usual objective and rational journalistic way, the life story of Lula, the current President of Brazil, during the period October 1st until November 3rd last year, when they gave a wide coverage of the Brazilian elections.}

\section{PALAVRAS-CHAVE (KEY WORDS)}

- Eleições brasileiras de 2002 (2002 Brazilian elections)

- Narrativas jornalísticas (Journalistic narratives)

- Jornais espanhóis (Spanish newspapers)

\section{Christa Berger}

UFRGS

Luiz Gonzaga Motta

UnB

\section{História da carochinha}

Era uma vez um menino pobre, que vivia perdido nos ermos de uma região árida de um reino imaginário. $\mathrm{O}$ rei era um homem mau, ele e os seus amigos tinham muita coisa, comiam muito. Um dragão horroroso, com uma enorme língua de fogo protegia as maldades do rei. A maioria das pessoas passava fome, quem podia ia embora. $\mathrm{O}$ pai do menino foi e largou para trás a mãe e os seus sete filhos pequenos. Sem ter como dar de comer às crianças, a mãe do menino mudou-se para uma cidade grande. Depois de uma longa e sofrida viagem, chegaram. O menino logo começou a trabalhar como engraxate, limpando as botas dos militares, amigos do rei. Com o dinheirinho que ganhava, ajudava sua mãe. Estudou enquanto pôde e foi trabalhar numa fábrica de carruagens para os ricos. Certo dia, uma máquina cortou um dos seus dedos. Doeu muito, mas o menino seguiu trabalhando porque precisava do emprego.

Uma noite, enquanto ele olhava distraído para a lua, apareceu um mago de barbas longas que the deu muitos conselhos sábios e disse: seja bom, organize os seus amigos e lutem contra o dragão. Não desanime nunca, você conseguirá derrotá-lo. O menino virou homem, seguiu os conselhos do sábio e começou a lutar contra o dragão da maldade. Foi preso pelos generais do rei, mas conseguiu escapulir e continuou lutando. Cada vez que falava, mais gente se juntava a ele. Parecia o flautista mágico, que tocava a flauta e atraía a todos. As pessoas pobres gostavam muito dele e diziam que, juntos dele, se sentiam mais 
corajosas. Sempre que o menino conseguia passar pelo dragão, batia na porta do palácio, mas o rei não o recebia.

Toda vez que começava a desanimar, ele percebia a presença do mago lá em cima, piscando um olho para ele. Então, o rapazinho começava a lutar de novo e as pessoas o seguiam. A quantidade de amigos foi crescendo, crescendo, até que se deram conta que, juntos, eram maioria naquele reino. Continuaram lutando, derrotaram o dragão numa luta terrível e derrubaram a porta do palácio. Não houve jeito, o rei entregou a coroa de ouro ao rapazinho, agora já homem feito. Ele vendeu a coroa, deu o dinheiro para quem precisava e declarou: neste reino, ninguém mais passará fome. As pessoas ficaram felizes, e perceberam que tinham de permanecer juntas para derrotar o dragão da maldade, porque ele não havia morrido.

Acabou-se a história, quem não acredita, que conte outra melhor!

\section{A narrativa jornalística}

Qualquer leitor identifica de imediato que a historinha contada acima se refere à trajetória pessoal de Luiz Inácio Lula da Silva, eleito presidente do Brasil nas eleições de outubro de 2002 por consagradora maioria de votos. Como uma fábula, a história começa com a expressão "Era uma vez...", que em português sempre introduz os contos maravilhosos, e termina também com uma frase de fechamento freqüentemente utilizada para encerrar as narrativas. Ambas, a introdução e a finalização, indicam que, durante a narração, o narrador solicita do ouvinte ou leitor uma suspensão dos fluxos de sentido homogêneos e rotineiros (sentidos de realidade) e a sua transposição para o nível da ficção, onde os efeitos de sentido são outros. A história está recheada de elementos típicos dos contos de fada, tais como um reino imaginário, um menino pobre protagonista, um rei mau e seu dragão (antagonistas), um mago bondoso, um conflito e a vitória final do bem. O uso intencional destes elementos em qualquer conto de fadas remete o ouvinte imediatamente ao tempo imaginário, ao illore tempore de que nos fala Mircea Eliade, o eterno tempo da narrativa mítica. No entanto, retirados os seus elementos de evasão ficcional, a história se refere a um ator e uma trama real, passada no Brasil nessa virada de século e narrada com palavras um pouco diferentes pela imprensa do mundo inteiro. Introduzimos o artigo com o conto para chamar a atenção para a riqueza dos elementos literários contidos na trajetória de vida de um menino pobre que se elege presidente da República onde nasceu, história que tem força narrativa suficiente para, por si própria, impor-se como valor principal de uma narrativa jornalística, revelando como mithos e logos se interpõem onde se supõe que deveria reinar a linguagem da objetividade e da racionalidade. É este relato literário que predomina como valornotícia na narrativa dos jornais espanhóis sobre a trajetória de Lula, até chegar à Presidência da República do Brasil em 2002, como veremos na análise a seguir.

Limitaremos a nossa análise a quatro jornais da Espanha, no período que vai de $1^{\circ}$ de outubro a 3 de novembro de 2002, tempo em que os jornais dedicaram ampla cobertura às eleições brasileiras $\left(1^{\circ} \mathrm{e} 2^{\circ}\right.$ turnos). ${ }^{2} \mathrm{~A}$ cobertura das eleições brasileiras por jornais de um país longínquo nos proporciona a oportunidade de observar os fenômenos que nos interessam nesta análise em uma imprensa que teve o distanciamento suficiente para realizar a sua cobertura, distanciamento que certamente não existiu nos jornais brasileiros. A riqueza do material produzido pela imprensa espanhola na cobertura das eleições de Luiz Inácio Lula da Silva como presidente do Brasil oferece uma oportunidade singular para a análise da narrativa jornalística e dos seus elementos mitopoéticos. ${ }^{3}$ Oferece ainda uma 
oportunidade para se verificar até onde a estrutura narrativa é uma qualidade per se, capaz de impor-se enquanto valor-notícia com mais força que outros componentes dos processos tradicionais de produção da realidade pelo jornalismo. Notamos que a figura de Lula e sua incomum trajetória de vida despertaram um interesse particular na imprensa espanhola, tornaram-se a grande notícia das eleições brasileiras, ocupando manchetes de todos os jornais e telejornais daquele país, centralizando o interesse jornalístico. Essa atenção pode ser compreendida a partir de alguns valores-notícia tradicionais, tais como recentidade, novidade, proeminência, impacto e interesse. No entanto, parece que a invulgar história de vida do político brasileiro, somada ao fato de ele representar uma tendência inversa à globalização liberal do mundo ocidental contemporâneo, despertou uma especial curiosidade jornalística e acabou se impondo como tema principal da cobertura, deixando, em muitos casos, o processo eleitoral e os fatores políticos e econômicos relegados a um segundo plano.

Centralizamos a análise da narrativa em torno da categoria "conflito" e da interação de contrários que existe em todo antagonismo. O conflito é tomado tanto como valor-notícia referente à história real quanto uma categoria própria da análise da narrativa. A categoria "conflito" solicita outras categorias fundamentais do relato que vão surgindo e gravitando em torno dela, tais como ações e reações, protagonista e antagonistas. Torna possível também uma interpretação da história enquanto narrativa do real e simultaneamente uma interpretação ao nível diegético desta história enquanto fábula. ${ }^{4}$ Centrar o foco no conflito nos permite, assim, navegar no plano dos acontecimentos históricos e, ao mesmo tempo, no plano dos "mundos possíveis". Ou seja, no plano histórico-ideológico por um lado e no plano criativo do imaginário, por outro. A trajetória inusitada de Lula enquanto político e enquanto candidato forneceu à imprensa espanhola todos os ingredientes que ela necessitava para contar uma intriga completa, onde não faltam conflitos, ações, tensões, protagonista e antagonistas, episódios reais diversos que, por outro lado, encadeiam um processo narrativo com princípio, meio e final (feliz, pelo menos até agora). A análise da narrativa nos proporciona uma oportunidade de focalizar a atenção no jogo entre objetividade e subjetividade da reportagem e salientar a construção de uma gramática narrativa que, a nosso ver, ficaria mais opaca em outros tipos de análise. Queremos deixar claro desde o início, portanto, que vamos situar nossa análise particularmente ao nível da sintaxe da história mais do que ao nível do discurso, embora não se possa prescindir das articulações do texto, estrutura que torna possível a construção de sentidos. ${ }^{5}$

É necessário ainda explicar que estamos tomando a narrativa ao nível da construção de sentidos que o leitor faz a partir do texto, mais do que ao nível da gramática interna da narratividade. Entendemos que a dramaticidade dos conflitos e tensões estimula leituras complementares para além dos sentidos explícitos "realistas" das notícias. O leitor acrescenta sentidos vários tornando o ato de recepção um ato de recriação. Em trabalho anterior, baseado na antropologia literária de Wolfgang Iser, L. G. Motta argumenta que todo texto (incluindo a notícia) é pontuado por lacunas e hiatos que têm de se "negociados" com o leitor, quem opera a interligação por conexões indeterminadas pelo texto, revelando um "jogo de interação entre o que está expresso e o que não está". O não expresso impulsiona a atividade de constituição de sentidos, porém sob o controle do que está expresso. Desse modo, o significado do texto resulta de uma retomada ou apropriação da experiência que o texto desencadeia e o leitor assimila e controla. ${ }^{6}$ Ou seja, consideraremos como 
estrutura narrativa objeto de nossa análise aquela que se constrói na relação entre o texto e leitor e não aquela que se articula e se esgota ao nível do relato propriamente dito. Por isso, estaremos investigando a narrativa em uma perspectiva mais próxima à psicologia social do que à teoria da literatura. Como nos dizem Cabruja, Íñiguez e Vázquez, para fazer a realidade inteligível os seres humanos necessitam recorrer a uma visão narrativa desta realidade, que por sua vez são narrativas e narrações que se entrecruzam e dialogam entre si e que "outorgam realidade" ao mundo em que vivemos. Quando nascemos, nós o fazemos em um mundo já construído. Isto significa que a linguagem nos incorpora e que nós vamos incorporando a linguagem mediante a adoção compartida de conceitos e de categorias que nos permitem explicar o mundo. São estes conceitos e categorias preexistentes que nos permitem ir assimilando e dando conta da realidade. Mediante nossas relações e práticas, acedemos a um mundo construído. ${ }^{7}$

Antes de entrar na análise propriamente dita, devemos precisar que a narrativa jornalística é singular, distinta de outras linguagens narrativas porque, além de não ter a mesma liberdade ficcional, como já dissemos, não possui a mesma linearidade seqüencial. É preciso, portanto, esclarecer um pouco mais sobre os nossos procedimentos metodológicos. A presente análise parte de um corpus composto por todas as notícias sobre as eleições brasileiras publicadas em quatro jornais espanhóis de grande circulação no período já definido, reconstituindo então uma narrativa única. Esta narrativa constitui-se em uma seqüência temporal fragmentada, mas unitária. As notícias que constituem nosso corpus de análise começaram a ser publicadas alguns dias antes da eleição, tomaram a freqüência quase diária nos dias imediatamente anteriores e posteriores à data das eleições, e gradualmente desapareceram das páginas dos jornais, na medida em que o fato deixou de ser novidade no início de novembro. Para nós, esta seqüência constituiu-se em uma narrativa jornalística com narratividade inerente, embora esta narratividade seja construída com a presença de inúmeras lacunas, típicas dos fragmentos de sentido que constituem as notícias diárias. A seqüência de notícias constitui-se assim em uma narrativa serializada por significados parciais que, somados, revelam uma história mais ou menos canônica e completa de sentido. Entendemos que o ordenamento da seqüência de notícias diárias sobre um mesmo assunto, efetuado pelo leitor, cria uma estrutura sintática entre as várias unidades nucleares (as notícias individuais) e confere ao todo um sentido de uma grande narrativa. Cada notícia relata uma ou mais ações e o conjunto destas ações gera reações em cadeia similares à estrutura de sintaxe da narrativa literária. Algumas vezes, uma só notícia assume a forma de uma narrativa interna: são as chamadas soft news, com estruturas narrativas de significado integral e fechado. Elas podem ser objeto de análise individual porque revelam uma dramaturgia inerente. Mas a maioria das notícias do nosso corpus não se constitui de sof news e sim de hard news, quase todas publicadas nas páginas do noticiário internacional ou de economia. Nestas notícias, embora o jornalista tenha com o leitor implícito um "contrato" diferente do contrato do leitor implicado típico da literatura, o jornalismo não escapa da narratividade, independente das intenções objetivas do jornalista-autor. Da mesma forma, o leitor das notícias lê os jornais de forma ativa, juntando fragmentos, trazendo para a leitura diária dos jornais sua memória coletiva que vai produzir a sua interpretação dos textos jornalísticos. Ao ler, o leitor introduz no universo do texto uma ética, uma estética, uma moral, mundos possíveis construídos progressivamente, cuja lógica não mais corresponde àquela do universo expresso pelas notícias. O leitor introduz no relato que lê as suas inferências e desejos, desenvolvendo 
mundos imaginados num processo de ideação e de modelização estética, moral e ideológica. ${ }^{8}$

O contexto jornalístico: Lula, objeto de curiosidade

Em outra análise, chamamos a atenção para o significativo interesse que as eleições presidenciais realizadas no Brasil despertaram na imprensa da Espanha, ocupando manchetes, capas dos jornais e preenchendo inúmeras páginas com farto material jornalístico, fotos e infografias. Concluímos que essa atenção inusitada pelas eleições brasileiras deve-se aos interesses econômicos internacionais, dos quais o Brasil hoje é parte importante, especialmente para os interesse financeiros da Espanha. ${ }^{9}$ Naquele artigo, mostramos que durante o segundo semestre de 2002, o conteúdo dos jornais da Espanha estava marcado por um noticiário negativo e pessimista. Durante este período, o atentado terrorista de Nova York completava um ano, provocando inúmeras reportagens retrospectivas. As notícias sobre a crise norte-americana em decorrência do atentado e sobre a estagnação econômica européia recheavam o noticiário. $\mathrm{Da}$ mesma maneira, a iminência de uma guerra contra o Iraque provocava uma série de matérias céticas em relação à situação mundial. Some-se a isto a decepção com a crise argentina, que trouxe prejuízos acentuados para a economia espanhola e o receio de que o mesmo pudesse se passar no Brasil com a eleição de um presidente de esquerda. Lembramos que os investimentos no Brasil representam 25\% de todos os investimentos estrangeiros da Espanha e que as grandes empresas espanholas investiram 50 milhões de euros neste país entre 1995 e 2001. Portanto, durante o período em que transcorriam as eleições brasileiras, predominava nos jornais espanhóis um noticiário permeado de ceticismo e receio do agravamento da crise pela eleição de um governo de esquerda no Brasil. As repetidas notícias sobre quedas na bolsa e no valor da moeda brasileira poderiam ser os primeiros indicadores. A conclusão é de que o farto noticiário sobre as eleições brasileiras refletia o interesse estratégico que o Brasil passou a ter para a economia mundial e espanhola, particularmente. ${ }^{10}$

$\mathrm{Na}$ presente análise, não abordaremos os aspectos econômicos da farta cobertura pelos jornais espanhóis das eleições no Brasil. Só voltaremos a eles quando forem necessários para explicar a narrativa jornalística da história de Lula. Mas queremos observar que é no ambiente deste noticiário sobre a iminência de uma crise econômica que se inscreve a narrativa jornalística da trajetória de Lula, sua personalidade, sua história. Para dar uma idéia do destaque dado pela imprensa espanhola à pessoa de Lula é interessante observar que durante semanas seguidas fotos do candidato foram utilizadas em inúmeros cadernos, variando desde as capas dos jornais às páginas de economia, do noticiário internacional aos suplementos especiais. No geral, as fotos publicadas oferecem uma imagem positiva do político brasileiro. Há diversas fotos em que Lula acena como um típico candidato, com braços abertos formando o $\mathrm{V}$ da vitória, outras com as mãos erguidas formando o L de Lula, outras ainda com a mão direita cerrada em sinal de força ou discursando em tom sério, em cima de palanques. Mas há uma profusão de fotos que igualmente oferecem uma imagem mais humana de Lula quando ele aparece sorridente, beijando bandeiras do Brasil, outras vezes ao lado de sua mulher, de José Dirceu ou de Marta Suplicy, ou ainda abraçando caciques indígenas (como não podia deixar de ser). Há uma foto de Lula no barbeiro, cortando a barba, que foi publicada, em diferentes ângulos, por inúmeros jornais espanhóis. Essas fotos têm uma significação especial porque desde Sierra Maestra, com os barbudos Fidel Castro e 
Che Guevara, a barba vasta passou a ser símbolo de esquerdismo revolucionário. Em diversos textos a barba aparada de Lula insinua um candidato mais conciliador e moderado. Finalmente, em relação às fotos, dois suplementos merecem ser destacados. Uma foto de Lula sorridente abraçando um cacique indígena com cocar de penas coloridas recobre toda a capa do suplemento "Revista", do jornal La Vanguardia, de Barcelona, no dia 6 de outubro, data da realização do primeiro turno. A foto transmite uma sensação de carinho do candidato para com o índio, que no exterior é o protótipo da imagem do brasileiro. Em outro destaque, já vitorioso no segundo turno, Lula aparece de braços abertos em enorme foto em cores, com a bandeira nacional ao fundo, ocupando toda a capa do suplemento "Domingo" do jornal El País, de Madri, no dia 3 de novembro. Lula está sorrindo e a foto sugere a imagem de um candidato vitorioso, de um político consagrado pelo povo.

Nos títulos e manchetes publicados pelos jornais da Espanha no período eleitoral o nome de Lula é repetido à exaustão. Além de ser notícia porque representa uma tendência à esquerda num mundo que tende para a direita e porque a sua história de vida é incomum, a concisão e a sonoridade da palavra Lula parecem favorecer sua repetição no imediatismo dos títulos jornalísticos. Nas manchetes de primeira página ou das páginas internas do jornal El País, por exemplo, está contada a vitória do candidato nos dois turnos das eleições brasileiras. Note-se que Lula é a notícia, muito mais do que as eleições em si mesmas. A palavra Lula abre a maioria das frases nos seguintes títulos: "Lula está a un solo punto de ganar en la primera vuelta en Brasil" ( $1^{\circ}$ de outubro); "Lula revive sus tiempos de líder sindical" e "Obreros y empresários arropan a Lula" (3 de outubro); "Lula promete mantener la autonomia ante EEUU para defender los interesses de Brasil" e "El guerrillero que puso la corbata a Lula" (4 de outubro);
"Lula pone a prueba sua nueva imagen de moderación" (6 de outubro) e "El izquerdista Lula, favorito en las elecciones de hoy" (subtítulo, no mesmo dia) "Lula rosa la mayoria absoluta" (7 de outubro); "Lula: Hemos tenido la mayor victoria de un partido de izquierdas en América Latina" e "Lula busca alianzas con sus rivales para ganar en la segunda vuelta en Brasil (8 de outubro); "La izquierda de Lula ganó en 24 de los 27 estados de Brasil" (9 de outubro); todas estas manchetes publicadas antes, durante ou depois do primeiro turno. A tendência se mantém no segundo turno ${ }^{11}$ : "Lula arrasa con el $61.2 \%$ de los votos" (28 de outubro); "Lo que Lula tiene que hacer" (3 de novembro); "Lula, otro Allende?" (8 de novembro); "Lula anuncia un pacto nacional contra la pobreza, la inflación y la corrupción" (9 de novembro). A seqüência de títulos conta a história inteira. Os outros jornais seguiram essa tendência. Assim, a figura de Lula centraliza a atenção das manchetes da imprensa espanhola, torna-se a grande notícia das eleições na Espanha. O seu nome parecia despertar curiosidade jornalística, parecia ser o que de novidade havia nas eleições brasileiras.

Antes de entrar na análise de Lula como personagem de uma história narrada pela imprensa, é preciso acrescentar mais duas observações a esta introdução, que revelam como se insere a narrativa propriamente dita no interior das notícias. A primeira delas se refere ao contexto interno brasileiro. Sob este aspecto, é preciso observar dois temas que se sobressaem nas reportagens. O primeiro se refere à imagem de moderação que em diversas matérias os jornais espanhóis atribuíram ao Partido dos Trabalhadores e ao candidato. Uma notícia publicada no El País no dia 3 de outubro chamava a atenção, no título, subtítulo e texto, para a aliança entre trabalhadores e empresários, destacava as declarações de Aluísio Mercadante sobre a abertura existente no PT atual e para a presença do empresário José Alencar na chapa e na marcha. Vale 
destacar que neste mesmo dia, no seu suplemento "Domingo", El País trata do que ele chama "a luta entre o realismo e a velha retórica do PT". Em alguns momentos, a matéria parece chamar o partido de Lula para mover-se rumo ao centro. No dia da realização do primeiro turno, matéria do El País destacava novamente no título e texto a imagem de moderação de Lula. O subtítulo desta matéria dizia que "o veterano sindicalista que dirigiu greves contra a ditadura culmina nas urnas sua larga marcha rumo ao centro" Por outro lado, dizia o texto: "Aparentemente, a transformação do antigo operário metalúrgico é notável: a povoada barba negra de ontem está branca e perfeitamente recortada, o terno e a gravata substituíram a indumentária descuidada, a gesticulação e os estabanões nos discursos políticos se suavizaram e sua mensagem eleitorial deu um poderoso giro rumo à moderação. Até o ponto em que empresários, banqueiros e militares aplaudem aquele que em datas muito recentes era considerado perigo público". Mas a matéria mais paradigmática sobre isto foi publicada nas páginas 2 e 3 do suplemento "Revista" do jornal La Vanguardia do mesmo dia 6 de outubro. Com o título "Una nueva izquierda.", salientava que Lula nada tinha que ver com a verborréia pseudo-revolucionária de Hugo Chávez nem com o autoritarismo de Fidel Castro e afirmava que se o PT de Lula agora é favorito, "é porque suavizou o seu discurso, se tornou mais light". As palavras em si falam mais do que qualquer análise.

Nesta mesma linha, um tema destacado pelos jornais na cobertura referese à necessidade de Lula compor "novas e surpreendentes" alianças. A matéria do dia 4 de outubro do jornal La Vanguardia destaca a necessidade de Lula fazer alianças para cumprir suas promessas. Título, subtítulo e texto salientam que o petista estará em minoria no Congresso e precisará compor politicamente para governar. Em vários momentos desta matéria, este jornal destaca a necessidade da participação da social democracia brasileira (PSDB) no novo governo porque "tem os melhores quadros políticos". No dia 8 de outubro, logo após o primeiro turno, El País observa em matéria de primeira página a procura de alianças de Lula para ganhar no segundo turno e destaca os contatos com Ciro Gomes e Anthony Garotinho. O tema se repete nas notícias do segundo turno das eleições brasileiras. O jornal El Mundo salienta em título da matéria do dia 27 de outubro que Lula se afasta da ala radical de seu partido para sair vitorioso e relata que o seu governo combinará reformas com pragmatismo. Em box embaixo desta matéria, também este jornal informa que poderá haver aliança entre o PT e os social-democratas do PSDB, que daria ao Brasil "o seu primeiro governo de unidade nacional em sua história". Após a vitória, o jornal El País traz novamente o tema da aliança em matéria de primeira página, mas desta vez uma coalizão dos "melhores do Brasil" contra a pobreza, a inflação e a corrupção, já agora com o nome de pacto nacional. Também aqui, não será preciso nenhuma análise para tornar evidente uma certa "torcida" dos jornais espanhóis pela moderação do candidato da esquerda brasileira.

A segunda observação que nos ajudará a situar melhor o contexto informativo da análise da narrativa que pretendemos desenvolver adiante se refere a definições sobre o papel das esquerdas, suas posições, as tensões das relações com investidores e com outros países. Esses temas foram objeto de algumas matérias publicadas pelos jornais espanhóis durante a cobertura do período eleitoral brasileiro e demarcam os contornos nos quais se inseriu a narrativa de Lula enquanto personagem. A matéria do La Vanguardia do dia $1^{\circ}$ de outubro traz uma acusação de Lula aos especuladores de boicotar o seu caminho rumo à presidência do Brasil, transcreve palavras duras do candidato contra o mercado financeiro que acusam os especuladores de "terrorismo 
econômico". Dois dias depois o jornal El Mundo publica matéria ilustrada por foto de Lula com olhar duro e expressão de raiva, cujo título destacava a "denúncia de uma trama para semear o caos". O subtítulo dizia que a equipe de Lula atribuía os distúrbios do Rio e de outras capitais brasileiras no período pré-eleitoral "a uma conspiração para semear o caos". Ou seja, se por um lado os jornais mostravam a moderação de Lula e seu partido, por outro também revelavam as posições agressivas do candidato e de seu partido em relação àqueles que consideravam inimigos. Neste clima de enfrentamentos pré-eleitorais, uma notícia publicada pelo enviado especial do El País na página 8 revelava a disposição firme de Lula "em defesa dos interesses do Brasil frente aos Estados Unidos. No sublide desta matéria uma frase de Lula sobre George Bush ilustra o seu posicionamento: "De cada dez palavras que pronuncia, nove são para declarar uma guerra". A cobertura não deixou de mostrar, portanto, o lado mais agressivo de Lula e do Partidos dos Trabalhadores durante o período eleitoral, e assim demarcava a posição do candidato à esquerda do espectro político.

Podemos concluir nossa análise sobre o "clima jornalístico" em que acontece a narrativa da trajetória de Lula, agora colocando-a de forma mais compreensiva no contexto editorial criado pela cobertura da imprensa espanhola das eleições brasileiras. Esta revisão prévia das notícias foi necessária não apenas porque revela o contexto em que a imprensa vai construir a história da trajetória de Lula enquanto personagem de um conto realista, mas também porque demonstra que, ao cobrir um acontecimento, a mídia cria outros acontecimentos na medida em que fala de algum lugar e a partir de um certo olhar. Este olhar jornalístico, como vimos, pontua certas ocorrências, privilegia ou omite outras, constrói um discurso que em si mesmo é um ato, uma realidade comunicativa com suas peculiaridades técnicas, políticas e ideológicas que Ihe são próprias e singulares. Recuperando o conjunto do que foi dito até agora sobre o contexto jornalístico da cobertura dos jornais da Espanha do período examinado, podemos concluir que estas eleições brasileiras mereceram um destaque inusitado na imprensa espanhola. ${ }^{12} \mathrm{Em}$ boa parte, este destaque parece refletir o interesse que os espanhóis em geral e as empresas espanholas em particular têm no Brasil contemporâneo devido aos investimentos feitos ali nos últimos anos. A cobertura revelou uma certa apreensão dos investidores espanhóis, preocupados com o que poderia se passar com o dinheiro investido no Brasil. Esta apreensão parecia transformar-se algumas vezes num medo de acontecer com o Brasil o que havia acontecido antes com a economia argentina. Isto explica, em parte pelo menos, a grande cobertura das eleições brasileiras pelos jornais espanhóis. Mas, por ser um candidato "contra a corrente liberal" que assola o mundo contemporâneo e por ser um político com uma história de vida singular, Lula "roubou a cena" e transformou-se em notícia ele próprio. Parecia haver muita curiosidade em torno da figura de Lula, ele se tornou a imagem das eleições brasileiras, ocupou praticamente todas as manchetes, suas fotos inundaram as páginas dos jornais e dos suplementos, seu nome foi repetido à exaustão. Esta excessiva atenção para com Lula não apenas lhe asseguraram visibilidade midiática, mas também contribuíram para legitimá-lo enquanto político e enquanto presidente de um país economicamente importante no mundo. Esta consagração do político brasileiro ocorre, entretanto, em um clima de enfrentamento internacional, de acirramento de conflitos mundiais, de estagnação e de recessão econômica. A seu modo, reportando os conflitos e as alianças, a imprensa deixou transparecer o seu desejo de tornar mais familiar e mais palatável a figura de Lula, realçando os 
seus novos compromissos políticos antes impensáveis, destacando o seu movimento rumo ao centro do espectro político, o novo realismo e pragmatismo do seu partido.

Por isto, não escapou à cobertura dos jornais espanhóis os enfrentamentos, os conflitos latentes e as tensões que marcaram as eleições brasileiras. A partir de agora, nos moveremos para a análise da narrativa propriamente dita centrando a análise em torno da categoria "conflito", como já advertimos.

Análise da narrativa: Lula e os conflitos políticos

No cenário de conflitos em torno dos interesses econômicos e políticos internacionais que compunham as páginas dos jornais da Espanha durante os meses de outubro e novembro de 2002, insere-se a cobertura das eleições no Brasil. Nunca é demais repetir que o conteúdo da imprensa estava recheado de notícias relativamente pessimistas sobre a crise internacional, as repercussões financeiras desencadeadas pelo 11 de setembro, a ameaça de guerra e os receios do que pudesse vir a ocorrer com o capital espanhol investido no exterior, especialmente no Brasil e na Argentina. Não é por acaso, portanto, que a eleição de um governo de esquerda no Brasil ocupasse tantas matérias indagadoras na imprensa espanhola. A repetição do contexto jornalístico em que se realiza a cobertura tem um objetivo analítico importante: relembrar as estratégias editoriais dos jornais. Consciente ou inconscientemente, eles tinham como objetivo chamar a atenção para certos aspectos das eleições brasileiras, destacar certos fatos, advertir a opinião pública espanhola, nomear, designar, contrastar, atribuir papéis aos novos líderes brasileiros. Repetindo estes aspectos, queremos destacar que aquilo que se comunica é mais do que aquilo que se diz, e chamar a atenção para o fato de que há outros significados para além dos conteúdos proposicionais dos enunciados das notícias. ${ }^{13}$ Sem nos preocupar aqui com a ordem da publicação das notícias, situaremos nossa interpretação inicial na discussão do conflito entre esquerda e direita no continente americano presente no noticiário, relembrando de passagem que, ao priorizar tais temas, a imprensa tornase ela própria uma personagem do conflito e do seu desenvolvimento. Ao reportar, a imprensa gera um novo ato, o ato de relatar de tal ou qual maneira e necessariamente torna-se ela própria agente do conflito. O confronto entre direita e esquerda, embora tenha perdido força no cenário internacional nos últimos anos, está significativamente presente no noticiário dos jornais espanhóis sobre as eleições no Brasil, onde as palavras izquierda, izquierdista e outras similares aparecem nos títulos, subtítulos e textos, quase sempre associadas ao nome de Lula. No dia $1^{\circ}$ de outubro, data do início de nossa observação, a expressão "candidato izquierdista" aparece em subtítulos do El País e do La Vanguardia, enquanto a expressão "líder izquierdista" está presente em subtítulo do El Mundo do dia 3 de outubro. O conservador ABC, como não poderia deixa de ser, estampa no dia 5 em manchete de primeira página: "El izquierdista Lula confirma su liderazgo". Logo de início, portanto, a imprensa nomeia e rotula o candidato. Ele passa a ser um "outro", um "diferente", um "izquierdista". No dia seguinte da vitória de Lula no primeiro turno, o La Vanguardia publica o seguinte título: "Eleições brasileiras, desafios do futuro - o grande dinamismo econômico do país e o possível triunfo da esquerda criam temores e expectativas", revelando explicitamente 0 receio europeu. O rótulo não é apenas imposto por iniciativa jornalística, obviamente. 0 próprio Lula contribui para diferenciar-se ao autonomear-se um líder da esquerda, conforme manchete de página do El País no dia 8 de outubro: "Lula: hemos tenido la mayor victoria de un partido de izquierdas en América Latina". No dia seguinte, El 
País utiliza a palavra novamente no seu título: "La izquierda de Lula ganó en 24 de los 27 Estados de Brasil". A autonomeação por parte de Lula revela uma tomada de posição consciente e intencional frente à direita, uma afirmação de identidade e de diferenciação em relação ao seu "outro". E a imprensa confirma e legitima o papel do candidato diferenciando e dimensionando-o, como ficará mais claro ao longo deste artigo. Para a nossa análise, fica a revelação por parte dos jornais de uma qualificação diferenciada, de uma marca que tem conotações ideológicas fortes, especialmente no panorama político latino-americano. Os rótulos "esquerda" e "esquerdista" qualificam, posicionam, identificam de que lado está a personagem e os seus antagonistas. Enquanto personagem, a qualificação de Lula pela imprensa revela de início o eixo em torno do qual vai girar a narrativa jornalística: toma o conflito como ponto de partida. Assim, desde as primeiras notícias encontramos a caracterização simbólica e o discurso identificador da personagem. Embora essa personagem seja ainda uma entidade difusa de significação que só vai adquirindo contorno mais preciso ao longo da narrativa, fica o registro do ponto de partida escolhido pelos jornalistas espanhóis na cobertura das eleições brasileiras.

A este respeito, duas matérias assinadas merecem comentário especial. A primeira, com o título "Una nueva izquierda", assinada por Joaquim Ibarz, foi publicada no suplemento "Revista" do jornal La Vanguardia no domingo 6 de outubro, quase todo dedicado às eleições brasileiras. O texto começa dizendo que, desde Allende, um líder de esquerda não chega ao poder por via democrática na América Latina, o que revelaria a maturidade da democracia brasileira. No segundo parágrafo, o autor chama a atenção para o fato de "um presidente nitidamente de esquerda governar a nona economia mundial". No entanto, diz o autor, a esquerda latinoamericana "terá que renunciar a muitos dogmas e intransigências se quiser seguir os passos de Lula", um dirigente que, segundo o articulista, nada tem a ver com a verborréia de Hugo Chávez, a corrupção e o populismo de alguns líderes mexicanos e o comunismo totalitário de Fidel Castro. E prossegue: o PT não é um partido marxista e radical e só é favorito para ganhar as eleições "porque suavizou o seu discurso". Um documento interno do PT, diz adiante o autor, afirma que "é necessário terminar com as utopias e ingenuidades que tantas vezes entusiasmaram e frustraram as propostas da esquerda brasileira". O PT hoje, conclui o texto, "se mostra mais como um partido social-democrata que como defensor dos postulados marxistas". Embora identifique "nitidamente" Lula com a esquerda e não deixe de ter razão, a matéria, como muitas outras, parece querer mover o candidato e seu partido para o centro do espectro político, para uma posição mais moderada, corresponda ou não isto à realidade. Outro artigo assinado por Josep M. Colomer, publicado no dia 8 de novembro no El País, mais de um mês depois da matéria anterior, intitulado "Lula, outro Allende?", também diz que, como Allende, Lula encabeçou uma candidatura "claramente de esquerda". Como Allende, diz o artigo, os partidos que apóiam Lula não terão maioria no Congresso e será preciso que ele faça alianças políticas para realizar as "reformas econômicas e sociais que pretende promover".

Novamente, o artigo diferencia Lula de outros líderes esquerdistas latinoamericano atuais, argumenta que o político brasileiro necessita fazer alianças com o centro e nomeia explicitamente os socialdemocratas e outros partidos de centro. As duas matérias revelam com clareza um ponto de vista: ambas parecem "solicitar" um movimento de Lula rumo ao centro do espectro político, parecem querer indicar que só há um caminho para o candidato ter sucesso em seu governo, aliar-se a 
partidos moderados. Assim, os jornais vão tecendo a narrativa de Lula como parte de um antigo conflito latino-americano entre esquerda e direita que, segundo os artigos, parece se repetir. Não é casual a presença do nome de Salvador Allende nem as comparações com Hugo Chávez e Fidel Castro nas duas matérias. Os articulistas designam para Lula um lugar no embate político-ideológico, um lugar "nitidamente" ou "claramente" de esquerda (embora "insinuando" o seu movimento rumo ao centro) e o ex-presidente chileno é o modelo mais confrontado. Assim os jornais vão trazendo Lula, a novidade surpreendente e ameaçadora, para um quadro mais familiar compreendido. Ao mesmo tempo, participam do cenário como atores-autores ao tomarem sutis posições no jogo político. ${ }^{14}$

Alguns poderão objetar argumentando que os dois textos comentados são artigos assinados, não correspondem à posição dos dois jornais. Se em parte isto é correto, é preciso argumentar, por outro lado, que os artigos não são lidos por seus leitores como algo "à parte" do resto do noticiário.

Além do mais, o noticiário sobre as eleições está igualmente contaminado por notícias que demarcam posições para o candidato e para seu partido, selecionando, priorizando, enfatizando. Assim, assumem posições no jogo político através do emprego de certos verbos, adjetivos, expressões qualificativas e outros recursos de linguagem. Por exemplo, em sua primeira notícia sobre as eleições brasileiras no período de nossa análise ( $1^{\circ}$ de outubro), o jornal El País destaca discursos de Lula respondendo às suspeitas de Washington. No texto, o político brasileiro diz que conversa com Fidel Castro e Hugo Chávez, mas também com Fox e com outros líderes. Da mesma forma que os articulistas, o jornal parece querer destacar a posição independente do candidato ao transcrever uma frase onde Lula afirma que "um eventual governo sob minha presidência não teria preferência nas relações internacionais". Outra matéria do mesmo jornal, no dia 4 de outubro, destaca no título a promessa de Lula em manter relações de autonomia frente aos Estados Unidos e defender os interesses do Brasil. Repare-se, entretanto, que o jornal vai construindo a sua narrativa em torno do conflito de posições político-ideológicas. Observa o jornal no lide da notícia que, caso Lula chegue à presidência, as relações "entre o gigante do norte e o gigante do sul não serão fáceis". O conflito existe na realidade e toda a notícia revela um discurso verdadeiro do candidato tomando posições: "Voy a defender los interesses del pueblo brasileño", reproduz uma frase. No entanto, é o jornal quem conta neste momento, é o jornal quem seleciona, quem prioriza, quem enfatiza certas declarações e não outras e assim vai sugerindo uma interpretação. E como não poderia deixar de ser, o jornal prioriza o enfrentamento pois o conflito é o cerne da notícia enquanto forma de apreensão da realidade.

$\mathrm{Na}$ narrativa da imprensa espanhola sobre o processo eleitoral no Brasil o "outro" de Lula e do PT vai se delineando nitidamente como os Estados Unidos, que parece simbolizar a direita. A perspectiva de uma cobertura desde fora do país, desde a imprensa européia, parece privilegiar em primeiro plano os enfrentamentos internacionais mais do que os adversários e inimigos internos (embora estes não estejam ausentes, como vimos). E o faz a partir das marcas simbólicas dos confrontos político-ideológicos do mundo ainda com base na Guerra Fria e nas lutas pela libertação latino-americana dos anos 60 e 70, como veremos. ${ }^{15} \mathrm{Na}$ notícia do dia 4, cheia de declarações de Lula, El País enfatiza "el punto de mayor ficción entre Estados Unidos y Brasil es la propuesta de la ALCA", salienta que "desde a ótica de Washington, o Brasil mantém uma atitude obstrucionista" e opina: "El proceso de integración continental está empantanado por el proteccionismo estadounidense y la grave crise econômica latinoamericana". 
O assunto reaparece em inúmeras matérias deste jornal. No suplemento do dia 3 de novembro há um longo artigo das perspectivas sobre o Brasil após a vitória de Lula, assinado por Gabriel Guerra, que depois de mostrar as divergências da política externa brasileira com os Estados Unidos, afirma que "en los albores del nuevo milenio, Brasil busca su lugar en el mundo y tambiém su propria identidad". Há referências sobre as relações com outros países em outras notícias. Por exemplo, no dia 6 de outubro, La Vanguardia abre notícia com uma afirmação categórica: "America Latina está pendiente de Brasil", e justifica dizendo que a nona economia do mundo é a única capaz de influir sobre os seus vizinhos, especialmente depois da perda de influência da Argentina. A Argentina, entretanto, aparece mais como uma possível aliada do que como antagonista. No El País do dia 29 de outubro, após a vitória de Lula no segundo turno, a manchete de matéria produzida em Buenos Aires afirma que "Argentina espera reactivar el comercio con el Brasil de Lula" e ressalta que a vitória do petista desencadeia no país vizinho a esperança de um desenvolvimento mais acelerado do Mercosul. Este país, portanto, aparece na narrativa jornalística como um provável aliado de Lula no enfrentamento das negociações sobre o livre comércio americano.

Os Estados Unidos parecem não ser os únicos antagonistas de Lula no plano externo, entretanto. Há referências às vezes difusas, às vezes diretas, sobre a posição antagônica de Lula em relação aos especuladores financeiros internacionais, bancos e ao "mercado" na cobertura das eleições brasileiras. Interessante notar, de passagem, que o FMI, em outros tempos antagonista principal, é poucas vezes mencionado como adversário. 0 foco sobre os antagonismos agora está nos especuladores, inimigo que aparece mais imediatamente identificado devido à queda de valor da moeda brasileira frente ao dólar (identificada por alguns analistas como artificial), notícia que estava persistentemente na mídia desde meados do primeiro semestre de 2002. Já no dia $1^{\circ}$ de outubro, El País fazia referência a Lula subscrevendo as declarações de Fernando Henrique Cardoso sobre os especuladores, a quem ele acusa de "falta de responsabilidade". Neste mesmo dia, a manchete da página 8 é: "Lula da Silva acusa a los especuladores de boicotear su camino a la presidencia de Brasil". No texto, destaque para as declarações de Lula ao acusar os especuladores e bancos nacionais e internacionais de fazer "terrorismo econômico", de fazer "dinheiro fácil". Destaque ainda nesta matéria para a reprodução das acusações de Lula ao mercado em frases como "algunos tratan el mercado como un dios, pero no lo es". O jornal El Mundo do mesmo dia traz a citação de um colaborador de Lula dizendo que o PT tem em mãos provas de conexões entre o narcotráfico e máfias financeiras. Embora o jornal ironize levemente dizendo que o acusador não cite quem nem onde existam essas conexões, a notícia deixa transparecer que o "outro", a direita, pode ser também identificado no "mercado", nos bancos e nos especuladores.

São outros os antagonistas identificados no plano interno. Permanece nos jornais espanhóis a perspectiva de narrar as eleições brasileiras com base nas prováveis alianças internas. As oposições políticas internas aparecem em menor número, e são mais frágeis enquanto antagonistas, os conflitos não têm a força nem a tensão que predominam nos relatos relativos às forças externas e ao "mercado". Ainda que pertencendo a posições ideológicas diferentes, nenhum partido político brasileiro aparece como antagonista a Lula. Ao contrário, em diversas matérias, adversários eleitorais são mencionados mais como prováveis futuros parceiros que como antagonistas, como veremos adiante. No dia 3 de outubro os jornais El País e El Mundo trazem à 
cena outro tipo de antagonistas: os dois jornais espanhóis estampam fotos em que Lula aparece com uma expressão raivosa e acusações feitas por ele a uma conspiração entre narcotraficantes e especuladores. Referindo-se aos episódios do Rio de Janeiro (quando os traficantes fecharam o comércio) os jornais reproduzem frases de militantes petistas afirmando: "Primeiro, os especuladores internacionais arremetem contra a economia do país com o propósito de gerar uma crise associada ao 'radicalismo' de Lula, depois querem transladar a violência para as ruas". Um mês depois, com Lula já vitorioso no segundo turno, o El País volta ao tema em matéria assinada no seu suplemento de domingo intitulado "La revolución de octubre". Normal Gall, autor da reportagem, diz que uma das três áreas em que o novo governo terá de atuar com eficácia é a violência e a segurança pública. Segundo o jornal, Lula teria um lugar de honra na história brasileira se conseguir colocar em prática um programa de segurança que ponha fim à onda de homicídios, motins em presídios e seqüestros, que impõem uma mentalidade de estado de sítio às grandes cidades. Dificilmente poderia-se imaginar que o narcotráfico tenha força para transformar-se em oposição a Lula ou que tenha legitimidade junto à população para apresentar-se como força política (apesar de ser dos porões do submundo do crime que saíram forças paramilitares capazes de desestabilizar democracias latinoamericanas anteriormente). A menção a estes antagonistas nos jornais espanhóis parece ser pontual, portanto.

Internamente, as alianças políticas antes consideradas esdrúxulas ocupam mais espaço nas matérias dos jornais espanhóis que os enfrentamentos partidários. As coalizões políticas incluem os partidos, mas referem-se também às articulações do candidato e do seu partido com os movimentos sindicais e populares, e com os empresários.
Parece que essas novas e impensáveis alianças (especialmente com setores empresariais) suscitaram mais a atenção dos jornais enquanto notícia do que as coalizões partidárias em si mesmas. É importante dizer que na narrativa dos jornais espanhóis sobre a eleição, Lula enquanto personagem confunde-se com o seu partido, as coalizões políticas de um são apresentadas como sendo do outro, as representações partidárias são tomadas como pessoais, misturando-se em uma só entidade o homem e a instituição partidária. $\mathrm{Na}$ narrativa jornalística dos jornais espanhóis sobre as eleições brasileiras, como já observamos, Lula enquanto personagem tem um grande relevo, atraindo sobre a sua pessoa a síntese das ações e reações políticas, sendo citado como se fosse ele próprio uma síntese. ${ }^{16}$ Muitas matérias ora falam de Lula enquanto líder, ora do seu partido, como se fossem uma só personagem. Assim, as ações em um parágrafo ora falam de um, ora de outro sem destacar exatamente quem fala ou age e as alianças são atribuídas ora a Lula, ora ao partido. Preferimos, para a nossa análise, tratá-las enquanto ações diferenciadas entre a personagem central (Lula) e personagens secundárias (outros partidos, empresários, movimentos populares, sindicalistas). Desta forma, podemos identificá-las com mais identidade enquanto personagens participantes dos conflitos (ainda quando aliados).

Indicativo desta tendência é a primeira reportagem do esmerado suplemento "Revista" do jornal La Vanguardia (seis páginas dedicadas ao Brasil e a Lula) no domingo, 6 de outubro, data de realização do primeiro turno. Citando militantes, diz o autor que Lula é mais que um candidato, é um símbolo, encarna o Brasil. A matéria começa falando da origem humilde de Lula, mas logo afirma que inúmeros atores políticos como as comunidades de base, a luta camponesa, o movimento negro, o feminismo "encontraram em Lula o seu líder, e no PT, a plataforma que pode fazer ouvir 
as suas vozes", mesclando a personagem, o partido e o Brasil numa só entidade narrativa. Observem como estas figuras se confundem no texto seguinte, extraído da mesma matéria: "Lula ha sabido aglutinar de coletivos muy diversos descontentes... y a otros sectores dispuestos a acceder a un cambio revolucionário. El líder petista ha hecho de la regeneración ética de la política y el diálogo sus hejes de campaña, há apelado a un Brasil nacionalista pero no nacionalizado, $y$, obviando etiquetas de izquierda o derecha, ha llamado a recuperar la autoestima del país". Aqui, o leque de alianças atribuídas à candidatura de Lula e seu partido percorre desde os movimentos de base aos empresários, superando as ideologias e fundindo todas em uma complexa personagem "redonda", para permanecer na linguagem literária. Na matéria do dia 3 de outubro do El País um parágrafo fala das mudanças ocorridas no país desde que Lula liderava as greves no $A B C$, enquanto outro parágrafo logo a seguir afirma que o PT é o partido político mais representativo e mais aberto, passando de um a outro, como se o discurso de Lula continuasse naturalmente no do partido.

Particularmente ilustrativas são as inúmeras passagens de diversas notícias que tratam da aliança de Lula e do PT com os empresários (antes citados como seus maiores inimigos), com os militares e as classes médias. Neste aspecto, o discurso dos jornais parece referendar as alianças e acomodar em torno de Lula interesses nem sempre conciliáveis na prática. Neste sentido, em alguns casos, os autores das notícias parecem endossar uma aliança ampla que identificaram em torno de Lula para poder explicar aos leitores as razões de sua ampla vitória eleitoral. Veja-se este trecho da mesma reportagem do suplemento do $\mathrm{La}$ Vanguardia citada acima: "Los profisionales liberales apoyan mayoritariamente a Lula. Las clases media urbanas también. Los profesores y los empleados del sector público confian en que Lula acabe con la política de moderación salarial de últimos ocho años. $Y$ sectores tradicionalmente oligárquicos como los militares y los empresários, pese a no apoyar a Lula, han perdido el miedo al PT pues observan en este discurso nacionalista, que entronca con la tradición de los grandes estadistas brasileños, la posibilidad de que se alivien las restricciones presupuestárias para el ejército y de que se dinamice el mercado interno y se favoreçan las exportaciones". O mesmo intrincado exercício retórico é necessário para explicar o leque de alianças em torno de Lula em um artigo no suplemento "Domingo" do El País do dia 3 de novembro, já consolidada a vitória. Este artigo, entretanto, parece preferir um tom irônico ao colocar juntos todos os aliados: "La base del PT está en la burocrácia del Estado, el personal universitário, los sindicatos de enseñanza, los empleados de banca y hospitales, los okupas (invasores de apartamentos) y los trabajadores del sector informal, todos en incomoda alianza con católicos utópicos, trotskistas y anarquistas".

Com dificuldade para identificar quem exatamente estava elegendo Lula presidente do Brasil, os jornais espanhóis pareciam querer entrar eles mesmos nos debates, argumentando a favor de certas alianças, ainda que para isto tenham de disfarçar suas posições citando outras fontes. No suplemento de 6 de outubro do La Vanguardia, há um artigo assinado por Joaquin Ibarz, ao qual já nos referimos antes, em que 0 autor cita longamente o consultor político brasileiro Gaudêncio Torquato. Com citações do consultor, o texto vai construindo o argumento sobre a necessidade de Lula (ou o PT, citado alternadamente com o nome de Lula) negociar alianças com as forças políticas que havia derrotado eleitoralmente. Segundo o argumento, depois das eleições Lula teria de ser ainda mais pragmático em relação aos seus adversários ideológicos. Neste caso, o PSDB é apresentado como 
o partido com posições mais próximas às do $\mathrm{PT}$, pois "ambos nacieron en el centroizquierda y la izquierda". Não é raro encontrar fotos de Lula ao lado de Fernando Henrique, dizia o texto. E prosseguia: "Quadros políticos de ambos os partidos se confundem, depois de migrar de uma força à outra". Nesta última frase, identificamos novamente um desejo do articulista mais do que uma correspondência com a realidade político-partidária brasileira. A social-democracia brasileira, prossegue 0 artigo, "tem os melhores quadros políticos do país e o PT não vai querer desaproveitálos", conclui o artigo, citando o consultor. No dia 3 de novembro, El Mundo publica manchete de página dizendo que Lula se afasta da ala radical do seu partido e no pé da página estampa um comentário do seu enviado especial antecipando um "possível governo de unidade entre o PT e os socialdemocratas (PSDB). Para o jornalista, por trás dos bastidores, Lula e Serra estão articulando uma futura aliança, que "daria lugar ao primeiro governo de unidade nacional ao país". O envolvimento mais editorializado de todos os jornais sobre esses temas está, entretanto, no El País. Em uma posição nitidamente crítica a Lula, o jornal diz em matéria especial do dia 3 de novembro que o programa do PT é uma mistura de "jargão socialista e populista própria dos anos cinqüenta e sessenta". E finaliza assim, em tom de quase ameaça: "El pueblo brasileño se ha acostumbrado a la estabilidad y no va a tolerar una recaída en la tensión y la confusión de los ochenta y primeros noventa, cuando la inflación crónica aumentó hasta constituir los episódios de hiperinflación". Outro artigo deste mesmo suplemento, depois de historiar a instabilidade nos períodos de outros presidentes, faz um declarado elogio a Fernando Henrique Cardoso: "Quien supo estabilizar la economia y ponerla de nuevo en rumbo de crescimiento". "Con Cardoso - continua o jornal - el aliento volvió al país, pero trás un prometedor arranque, se topó con amargas realidades que no pudo superar, entre ellas la que será sin duda pesadilla para Lula: la falta de consensos y acuerdos políticos, tanto en el congreso como en las poderosísimas provincias". Aqui, não é necessária nenhuma análise para interpretar: o narrador está literalmente envolvido com a sua narrativa, sem disfarces, torcendo por uma aliança futura entre PT-PSDB ou uma movida de Lula rumo à social-democracia à européia.

\section{Lula, personagem de um conto de fadas}

Quando se referem ao Brasil, os jornais europeus parecem se dispor sempre a contar histórias, que nem sempre são realistas. Isto não quer dizer que os jornais relatem um país fictício, mas que a realidade brasileira parece aos olhares europeus um lugar extravagante, insólito e cruel. No dia 11 de junho de 2002, por exemplo, o jornal El País publica com destaque notícia sobre o assassinato do jornalista Tim Lopes, "julgado e condenado por um tribunal de delinqüentes" que começa assim: "El preságio se transformó en macabra realidad". O jornal El Mundo publica no dia 27 de outubro (dia da realização do segundo turno) notícia de página inteira ilustrada por foto de um menor com revólver na mão e o título: "Pistoleros de 12 Años". Diz a matéria que pelo menos 3 mil menores combatem na primeira linha de fogo das máfias e que morrem mais crianças no Rio de Janeiro por balas que na guerra do Oriente Médio. As duas matérias foram publicadas em datas próximas ao período eleitoral e revelam os absurdos de uma realidade inc ompreensivelmente cruel. As personagens destas histórias não são mais os exóticos índios das florestas, mas jovens criminosos das grandes cidades e as suas vítimas. No dia 17 de maio, o mesmo El País havia publicado matéria com o título: "Brasil, un conto de hadas". O título já indica o tom da matéria. Conta a história de meninos 
de favelas de "un país descompensado", onde a delinqüência forma parte da vida cotidiana e o futebol é visto como única saída, como num conto de fadas. Cita então os nomes e as histórias pessoais dos jogadores Ronaldo, Giovani, Rivaldo e Roberto Carlos, meninos pobres que se tornaram celebridades do futebol na Europa. Não é de se admirar, portanto, que a trajetória pessoal de Luiz Inácio Lula da Silva, um engraxate que chegou à presidência, tenha sido tão explorada como um conto maravilhoso pela imprensa espanhola.

Dois títulos de matérias sobre Lula no período analisado repetem este lugarcomum, comprovando o olhar europeu para um país extravagante. No dia 6 de outubro La Vanguardia de Barcelona estampa: "Lula - Una vida digna de telenovela" e no dia 28 de outubro o El País de Madri publica em sua editoria internacional: "Um presidente formado en la dureza de la vida - La biografia de Lula es un vivo retrato de las fortunas y miserias del país que ahora le tocará dirigir". Os títulos antecipam aquilo que foi o prato preferido da imprensa espanhola durante semanas: a trajetória de vida de um menino que saiu do miserável Nordeste brasileiro, passou fome, foi abandonado com a mãe pelo pai, migrou para a cidade grande, trabalhou de engraxate, empregou-se como metalúrgico, perdeu um dedo da mão na fábrica, começou a militar no movimento sindical, lutou contra a ditadura dos militares, organizou greves, foi preso, continuou militando, organizou um partido político, candidatou-se várias vezes ao Palácio do Planalto até que finalmente convenceu o seu povo e foi conduzido pelo voto à Presidência da República. Os ingredientes de um conto de fadas estão todos aí, fornecidos pela exótica e cruel realidade brasileira, faltava apenas tecer 0 enredo e contá-lo, com detalhes e emoção, como convém a todo conto bem contado. $O$ público europeu, como os demais, gosta de ouvir histórias, principalmente com tantos elementos dramáticos juntos.

Antes de continuar a análise é necessário dizer que, a nosso ver, a imprensa realiza, através do "trabalho da notícia", um percurso cognitivo, um ciclo do não-familiar ao familiar. Ela traz o "não-familiar" para o terreno do familiar, ou dito de outra forma, traz o relato do inusitado para o interior do mundo das coerências firmemente estabelecidas dos nossos cotidianos. As primeiras notícias que a imprensa divulga sobre algum fato diferente, como este nordestino iletrado que se atreve a se candidatar à presidência de um "país gigantesco", colidem com os sentidos estabelecidos no mundo ordenado das rotinas. Após - estranhamento inicial, a imprensa procura explicar o fenômeno e ajudar seus leitores a digerir este "não-familiar". Aos poucos, imprensa vai redimensionando o "não-familiar", vai tecendo as relações e construindo causas e explicações plausíveis até transformá-lo em algo conhecido, explicado, digerível. Ou seja, algo que agora já pode ser compreendido e assimilado como familiar.

A nosso ver, este é o trabalho realizado pela notícia, trabalho realizado pelas várias histórias que foram contadas pelos jornais espanhóis durante o período eleitoral sobre a inusitada história de um menino pobre que se torna presidente de um grande país, como veremos. As diversas histórias contadas pelos jornais foram "introduzindo" o singular "fenômeno Lula" no universo de referência simbólica do público europeu e processando gradualmente os significados de uma aventura incomum. O trabalho de "familiarização" do fenômeno Lula desenvolve-se com a divulgação regular das notícias episódicas pela imprensa espanhola na cobertura do dia a dia, que vão compondo uma história única a partir dos sentidos fragmentados. Estas notícias foram analisadas acima. Algumas notícias, entretanto, dedicam-se quase exclusivamente a esta explicação, procuram contar histórias integrais e são, 
em si mesmas, narrativas completas. São as notícias conhecidas como fait divers ou soft news. Particularmente estas notícias nos dedicaremos agora.

É bom esclarecer que a publicação das notícias com as histórias pessoais de Lula não se deve apenas à sua dramática vida pessoal nem ao trabalho de familiarização promovido pelas notícias, para o qual estamos chamando a atenção, entretanto. A revelação do lado humano do líder petista, sua trajetória, seus amores e desencantos pela vida foi produto também da própria estratégia mercadológica bemsucedida dos assessores da campanha presidencial, especialmente pelo publicitário Duda Mendonça, num esforço para tornar a personagem menos vinculada às durezas da política e revelar o lado pessoal e emocional do candidato. Os próprios jornais espanhóis explicam isto. No dia 6 de outubro o jornal El País publica matéria sobre a imagem moderada de Lula e revela a estratégia publicitária de Duda Mendonça: "Mi trabajo consiste em dejar que Lula sea él mismo", diz ele. "En elecciones pasadas estaba preso del discurso, no sonreia; su esposa apenas participava en la campaña, no se mostraban en la família. Esta vez hemos mostrado Lula persona, tal como es en la vida real: cariñoso, asequible, de buen humor. Son facetas que siempre se habían ocultado para mostrar al hombre político, duro." Vale a pena transcrever uma citação mais longa do publicitário na mesma reportagem, aclaradora da transformação do candidato: "Lula es un tipo muy emocional y la historia del PT es una historia cargada de emociones. El Lula más light no significa que haya hecho concessiones de contenido. Todo lo contrário. Dice las mismas cosas que antes, pero de una forma más tranquila. Antes se irritaba ante una pregunta desagradable. Le mostré que con una pregunta desagradable, puede conquistar un voto sí da una buena respuesta".

Em parte, a estratégia publicitária ajuda a compreender por que o lado humano de Lula surge com tanta força nas notícias sobre as eleições brasileiras. Realçando o lado pessoal e afetivo, a estratégia de campanha repercute na abordagem jornalística.

A imprensa espanhola não ficou imune a esta contaminação, obviamente. A matéria do La Vanguardia do dia 6 de outubro que se intitula "Una vida digna de novela" começa com uma frase reveladora da perspectiva dramática das matérias de interesse humano em torno do candidato: "La vida de Lula podria dar pie a una telenovela con muchas lágrimas, emociones, dolores, y alegrias". Lula se transformou, assim, na personagem antropocêntrica das narrativas jornalísticas sobre as eleições, fascinando os jornalistas com a sua comovente história pessoal. Em torno de sua figura os jornais teciam intrigas em que a sua trajetória pessoal se assemelha àquela de muitos heróis literários, revelando em episódios diversos a sua inusitada história. Nas matérias de interesse humano (soft news) existe um processo de elaboração estética em que o material apresentado faz a ordenação linear onde as ações vão se sucedendo temporalmente, construindo a fábula. No plano da intriga jornalística os eventos vão se encadeando, estimulando a curiosidade dos leitores e solicitando a complementação de sentidos, como podemos ver nos títulos e textos: "Tuvo una infancia que se compara a un personaje de Dickens. Dias antes de nascer (en una paupérrima población de Pernambuco) su padre abandonó el hogar familiar y a sus siete hijos" (La Vanguardia, 6 de outubro). "Su madre se transformó en un símbolo de la nordestina pobre, marginalizada pero resistente y heróica" (La Vanguardia, 6 de outubro). "Mio padre era un pozo de ignorancia", recorda Lula no El País (29 de outubro): "No comia el pan que nosotros comíamos...lo guardaba en un armário y nadie lo podia tocar", continua. O enredo literário-jornalístico vai sendo tecido: "Dona Lindu (mãe de Lula) empreendió con sus hijos un largo camino a Sao Paulo en 
busca de un futuro menos indigno: trece dias en caminón, casi a pan y agua. Lula apenas tenia 7 años" (La Vanguardia, 6 de outubro). "En las calles de Santos tuvo su primer trabajo de vendedor ambulante. A los 15, logró una plaza para un curso de tornero mecánico y ingresó en una fábrica" (El País, 6 de outubro). "En 1975 ya era presidente del sindicato metalúrgico. En 1977 se acercó a los sectores de izquierda y (pasó) a defender las libertades políticas. Pronto mostró su capacidad negociadora y su cintura política. En 1979 fundó la central de trabajadores y en 1980 el Partido de los Trabajadores" (La Vanguardia, 6 de outubro). En 1980 encabezó la mayor huelga de los metalúrgicos, estuvo detenido durante 31 dias y se elegió deputado con un millión de votos" (El País, 6 de outubro). Encurtamos deliberadamente o enredo da história, pois a proliferação de episódios sobre a vida de Lula espalha-se em toda a cobertura jornalística. Passemos agora à análise da representação que esta história construiu durante as eleições como símbolo das mudanças de um país inteiro. ${ }^{17}$

$\mathrm{Na}$ figura dos heróis de muitas narrativas literárias está representada não apenas a trajetória individual da personagem, mas desgraças, misérias e ideais muito mais amplos, desejos, sonhos e utopias da comunidade à qual pertence. Não poderia ser diferente com a narrativa jornalística em torno de Lula. Em diversos momentos da cobertura, ele personifica a nacionalidade singular atribuída ao Brasil, país "desbalançado", "desigual" e "contraditório" e utópico. Matéria do El País do dia 28 de novembro noticiava a vitória de Lula e dizia: "Ahora llega a la Presidencia de la República un ciudadano de origem humilde nacido en el Brasil profundo y hostil, el sertao, tan olvidado como despreciado por las élites que han governado desde la independencia". Outra notícia do El País neste mesmo dia abre relatando o episódio em que Lula perde um dedo da mão e diz: "Todo un simbolo de un país amputado por las enormes carencias sociales que sufre". Logo adiante, continua o texto: "La vida de Luiz Inácio Lula da Silva es, desde el dia de su nascimiento, un vivo retrato de las fortunas y misérias del Brasil". E mais adiante: "Compreender la história de Lula y de la família Silva es compreender la história reciente de Brasil en el más amplo sentido. Los Silva simbolizam mucho de lo que poderia llamarse caráter nacional, y el apellido es tan comun en Brasil como los Garcia en España". Se para a imprensa espanhola Lula encarna o Brasil mais profundo, encarna também os sonhos épicos de uma nação. No dia 6 de outubro matéria do La Vanguardia tinha o seguinte título: "Brasil pone sus sueños en Lula". Na boca de um eleitor, a matéria diz textualmente: "Lula da Silva es más que un candidato, es un símbolo. Encarna a Brasil. Es todo lo opuesto que ha gobernado desde la independencia en 1822... Si ganar, Brasil entrará en una nueva era. Simplesmente porque tendrá como presidente a un tornero", conclui.

\section{Conclusões}

Identificamos duas narrativas que correm paralelas na cobertura dos jornais espanhóis das eleições brasileiras. A primeira delas é a grande narrativa do país Brasil, embora nas manchetes, títulos e textos dos jornais analisados o país ganhasse outro nome, chamava-se Lula da Silva. Mas aparece com força histórica a narrativa das transformações recentes de uma nação que ganha importância no jogo das relações internacionais. Por isso mesmo, o que acontece ali passou a ser observado com muito mais interesse do que antes. A segunda narrativa se refere particularmente a esse menino pobre, migrante nordestino que começa a vida como engraxate, torna-se líder operário, político influente e presidente do país. As duas narrativas se confundem no grande enredo de uma nação, falar de um deles no momento eleitoral passou a ser falar 
igualmente do outro. Até porque a singular e surpreendente história pessoal de Lula da Silva, no entendimento dos jornais europeus, simboliza a própria história recente do seu contraditório país.

A análise revela que os jornais realizaram uma cobertura, como não poderia deixar de ser, com olhos de europeus, com um olhar curioso e indagador sobre o que exatamente estava se passando neste gigantesco país longínquo, exótico e cruel. Jornais e jornalistas pareciam se indagar como pode ou como se atreve um líder operário pobre e iletrado chegar à presidência da República de um país tão promissor. Pareciam se perguntar qual o significado de tudo aquilo e tratavam de entendê-lo para poder explicá-lo. Os jornais pareciam funcionar como observadores avançados das empresas e do público espanhol, ansiosos frente ao que estava acontecendo em terras brasileiras e apreensivos com o que pudesse vir a ocorrer com os capitais ali investidos. Jornais e jornalistas pareciam algo incrédulo e surpresos com a tendência do Brasil dar uma guinada política à esquerda num momento em que o mundo todo parece inclinar-se para uma globalização à direita.

O procedimento de analisar os relatos noticiosos através de uma categoria como o conflito revelou-se útil para entender o desenlace dos fatos a partir dos enfrentamentos históricos e proporcionou a oportunidade de observar como as personagens e ações vão tecendo uma narrativa jornalística de enredos pseudoliterários. Estes enredos são estruturadores e nomeadores dos papéis dos protagonistas e antagonistas, dos cenários e encadeamentos de uma sintaxe narrativa jornalística onde se realiza o jogo de sentidos entre o logos e o mhythos, o objetivo e o subjetivo. Nele estão presentes a narrativa da história e a história narrativa que revela a fábula, e assim vão se construindo os sentidos. Significações que parecem cumprir o papel de tornar familiar o que à primeira vista parecia nãofamiliar. É este o trabalho que parecem realizar as notícias sobre Lula: dimensionar o estranho, confrontá-lo com a ordem conhecida, avaliá-lo e assimilá-lo a partir dos padrões vigentes, se possível influindo para a moderação dos "radicalismos".

Assim, o excessivo número de fotos nas capas e páginas dos jornais espanhóis vai tornando conhecido o desconhecido. O abusivo uso do nome de Lula nas manchetes, chamadas e títulos como sujeito das frases vai ensinando o novo léxico. Vai-se criando o novo sujeito da história que se há de aprender. Os jornais europeus vão criando a compreensão da personagem disconforme, exótica, barbuda, iletrada, conforme a estabilidade da ordem vigente. Assim, no jogo de encontros e desencontros, a narrativa jornalística vai priorizando temas, personagens, enfrentamentos e alianças conforme os universos europeus e de acordo com as suas intenções. O radical, o invulgar, o singular vão sendo aos poucos civilizados, domesticados, dominados. Uma vez mais se repete a história: o exótico tropical vai se transformando em uma explicação possível para o olhar europeu. A imagem de moderação ameniza os confrontos, a necessidade de alianças e de movimentos rumo ao centro ganha dimensão noticiosa maior do que na realidade histórica e torna mais palatável a diferença. Neste processo, a identidade exótica torna-se familiar, mas sua identidade é nomeada pelos rótulos do sujeito "outro" político: esquerda, esquerdista, radical. Ao nomeá-lo, identifica-se também o antagonista político: a civilização, o mercado, os investidores, "nosotros". Assimila-se, pois, o sujeito exótico, mas sem deixar de manter com ele uma distância preventiva. Foi assim que vimos a narrativa da imprensa espanhola das eleições no Brasil .

\section{Notas}


1 Trabalho produzido durante o período de pós-doutorado do prof. Luiz G. Motta (UnB), com bolsa do CNPq, e da profa. Christa Berger (UFRGS), com bolsa da CAPES, ambos em Barcelona, Espanha.

2 Os quatro jornal são El País, El Mundo e ABC, de Madri, e La Vanguardia, de Barcelona, todos de circulação nacional. Recorreremos eventualmente a algumas reportagens $e$ artigos publicados em data anterior ou posterior ao período eleitoral para ilustrar alguns pontos de vista. Mas o período entre $1^{\circ}$ de outubro e 3 de novembro foi o período em que as eleições brasileiras ocuparam fartamente as páginas dos jornais espanhóis enquanto notícia e compõe-se no corpus principal de nossa análise.

3 Em outro trabalho, revelamos como a estagnação econômica européia e a ameaça potencial que a eleição de Luiz Inácio Lula da Silva representava para o grande capital resultaram em uma cobertura exaustiva do processo eleitoral brasileira pela imprensa espanhola. Ver Christa Berger e Luiz Gonzaga Motta, "A Cobertura das Eleições Brasileiras pela Imprensa Espanhola: Brasil Grande Potência?", Barcelona, 2002

4 Hector Borrat postula que 0 conflito é o valor primordial para decidir inclusões, exclusões e hierarquização, não apenas na cadeia da notícia como também ao longo de todo o ciclo informativo e o relaciona com a narra-tividade jornalística: "É o primado do relato que dota o conflito de um reino sem fronteiras, que se estende por todos os relatos, os históricos, mas também os de ficção. Todo relato necessita de um protagonista e todo protagonista, para existir como tal, necessita por sua vez de um antagonista com quem dirimir um agon, uma luta: uma interação de conflitos", in H. Borrat, El primado del relato, Análisi 25, 2000, pag. 49

5 A interpretação não seguirá nenhum plano sistemático, fora das exigências da análise da narrativa. Aqueles que esperam uma análise quantitativa ou sistemática se decepcionarão. A nossa opção epistemológica é outra.

6 Motta, Luiz Gonzaga: Conflito político e geração de sentido nas notícias: a saga do menino Elián, Cadernos CEAM, Ano II, nº 6, 2001, pag. 33-59

7 Cabruja, Teresa, Lupicinio Iñiguez e Félix Vázquez: "Como construímos el mundo: relativismo, espacios de relación y narratividad", in Analisi no 25, Barcelona, 2000, pag. 61-94. Os autores parecem endossar as palabras de J. Potter em "La Representación de la realidad - Discursos, retórica y construcción social", Barcelona, Piados, 1998. Para Potter, a realidade "se introduz" nas práticas humanas por meio das categorias e das descrições que formam parte dessas práticas. 0 mundo não está categorizado de antemão por Deus ou pela natureza de uma maneira que todos nos vemos obrigados a aceitar. Se constrói de uma ou de outra maneira à medida que as pessoas falam, escrevem e discutem sobre este mundo (pag. 130).

8 A metodologia da análise narrativa jornalística proposta foi desenvolvida por Luiz Gonzaga Motta em "Explorações epistemológicas em torno a uma antropologia da notícia", artigo a ser publicado na Revista Intercom, S. Paulo, 2002. Aplicação desta metodologia pode ser encontrada também em Luiz Gonzaga Motta: "Conflito político e geração de sentido nas notícias: a saga do menino Elián, Cadernos CEAM n. 6, Ano Il, 2001, pag. 33-59.

9 Berger, C. e L. G. Motta, "Brasil, Grande Potência: a Cobertura das Eleições Brasileiras pela Imprensa Espanhola", op. cit.

10 Neste aspecto, 0 jornal conservador $A B C$ foi o mais explícito. No dia 3 de outubro, por exemplo, dizia abertamente em chamada de primeira página: "Telefónica, pendiente de las elecciones en Brasil, donde se genera el 30 por ciento de su negocio total." 0 título da matéria interna era: "Los fuertes interesses económicos de España esperan sobreponerse al 'efecto Lula". No dia 28 de outubro este jornal volta a estampar em manchete de página: "Las multinacionales españolas instaladas en Brasil acogen con cautela el triunfo de Lula."

11 Por ocasião do segundo turno, os jornais espanhóis diminuíram sensivelmente 0 volume da cobertura sobre as eleições brasileiras, comparando com o primeiro. Por um lado, porque os resultados foram antecipados pelas pesquisas. Por outro, o noticiário sobre as eleições foi deslocado para segundo plano por causa da cobertura da trágica invasão de um teatro em Moscou por ativistas chechenos, com dramáticas conseqüências, ocorrida no mesmo período.

12 Já explicamos anteriormente o inusitado interesse sobre as eleições brasileiras devido às fortes inversões espanholas 
no Brasil nos últimos anos. Já observamos também que, no segundo turno, o volume de matérias diminuiu muito em relação ao primeiro, devido à unanimidade das previsões e à tragica invasão de um teatro em Moscou pelos ativistas chechenos, que teve privilegiada e dramática cobertura.

13 Estamos nos referindo aqui às implicações conversacionais que derivam diretamente dos significados das palavras ou do contexto do ato comunicativo. 0 "ambiente" em que ocorre a cobertura sugere outros significados pragmáticos além do conteúdo informacional das notícias sobre as eleições.

14 Em editorial no dia 8 de outurbro, La Vanguardia diz que, desde 0 ponto de vista da estabilidade financeira, seria preferível Lula ganhar no primeiro turno. Mas "no hay malo que por bien no venga" e afirma expressamente que no lapso de tempo entre o primeiro e o segundo turno, Lula pode "consolidar aún más su arduamente adquirida imagem de pragmatismo y moderación".

15 Os jornais espanhóis reproduziram a declaração do exsenador negro norte-americano Jesse Jackson, presente no comício do dia 31 de setembro em São Bernardo, em que ele comparava Lula a Marthin Luther King e Nelson Mandela e sua acusação a $G$. Bush como responsável por espalhar a fome e a dor no mundo com a guerra.

16 Temos evitado utilizar aqui o termo herói pela força mítica que esta figura tem. Isto poderia influir e modificar a análise que vimos desenvolvendo, onde preferimos uma abordagem do tipo simbólico-realista. No entanto, literariamente definida, a figura do herói tem muito a ver com o papel desempenhado por Lula na narrativa jornalística que temos examinado. Todo o relato da imprensa espanhola parece girar em torno dele como figura central que organiza as ações, o tempo e cenários da narrativa jornalística, não apenas no plano político como no plano psicológico, remetendo algumas vezes para os planos simbólicos do percurso acidentado do herói e para momentos triunfalistas, como estamos vendo através da análise.

17 Durante a campanha, foram publicadas outras histórias pessoais de outras pessoas que complementam e explicam partes obscuras do enredo da personagem Lula. Infelizmente, não poderemos analisá-las aqui. Por exemplo, no dia 4 de outubro, El País publica ampla matéria sobre a vida de José Dirceu, "el guerrillero que há puesto la corbata em Lula", segundo o título. $\mathrm{Na}$ matéria, o jornal conta a "vida rocambolesca" deste exlíder estudantil radical (cuja vida poderia ser objeto de um filme, diz o próprio jornal) que se transformou em político elegante, eloqüente, "cerebro político de Lula hoje". No dia 27 de outubro a revista Magazine distribuída com a edição de domingo do La Vanguardia publica primorosa matéria assinada de 12 páginas e foto de capa com a história pessoal de oito personagens diferentes, pretendendo mostrar a diversidade dos eleitores de Lula. 